\title{
Modeling of Catalyst Layer for PEM Fuel Cell: MATLAB Approach
}

\author{
Susmita Singh ${ }^{1}$ Pushan Kumar Dutta ${ }^{2}$ \\ ${ }^{1}$ Department of Chemistry, Amity University, Kolkata, West Bengal, India \\ ${ }^{2}$ Department of Electronics and Communication Engineering, Amity University, Kolkata, West Bengal, India
}

(Received 10 January 2021; revised manuscript received 17 June 2021; published online 25 June 2021)

\begin{abstract}
The Polymer Electrolyte Membrane Fuel Cell (PEMFC) has become an upcoming fuel cell technology for stationary as well as transportation applications. This work presents modelling of catalyst layer for PEMFC system through MATLAB. Catalyst layer modelling is a multi-variable and multi-objective problem. Modelling of the catalyst layer ranges from zero to three dimensions. The actual structure of the catalyst layer is not being considered by zero-dimensional models. Overall changes in the catalyst layer are depicted by one-dimensional models. Two- and three-dimensional models account for the catalyst layer and the agglomerate. This work presents a dynamic model of the catalyst layer for PEMFC system by using MATLAB that can be used for the development of the catalyst layer for the same. The proposed model includes various operating conditions. The focus of catalyst layer modelling is to go beyond empirically describing the characteristics of the fuel cell and the modelling is done based on certain parameters with direct physical meaning. This model is being used to predict the enhanced performance of the catalyst layer as a function of such measurable characteristics as catalyst intrinsic activity, effective surface area, agglomerate size, improved electrode materials etc. A few simplifying assumptions make the model quite easier in computational demand and therefore compliant to simulate not only the catalyst layer but also the entire cell system. Despite these assumptions, the model reproduces experimental data well. Moreover, it is observed that the proposed dynamic model of the catalyst is very useful in comparison with the chemically synthesized catalysts.
\end{abstract}

Keywords: PEM fuel cell, Renewable energy, Catalyst layer, Dynamic model.

DOI: $10.21272 /$ jnep.13(3).03012

PACS number: 82.47.Gh

\section{INTRODUCTION}

Electrochemical reactions take place at porous, thin catalyst layers of electrodes in fuel cell. In PEMFC, the gas diffusion electrodes [1,2] are made of an active layer supported on a porous backing (a carbon cloth); the active layer contains the supported (mainly different allotropes of carbon) noble or non-noble metalbased catalysts. The catalyst layer specifically anode catalysts should be very effective for the dissociation of fuels into protons and electrons, containing high surface area, and considerably low cost. The catalyst layers are generally the thinnest layer in the membrane electrode assembly of the fuel cell (5-30 microns even in the range of $\mathrm{nm}$ ) but considered as the most complex part due to its multiple phases, porosity, and electrochemical reactions. Fig. 1 describes a schematic of the PEM fuel cell catalyst layers where the electrochemical reactions take place at the interphase between the electrolyte and electrocatalyst.

To catalyse reactions at two electrodes, catalyst particles must have contact to electronic and protonic conductors. Moreover, there must be pathways for reactants to contact the catalyst sites and for products to exit. At three phase interface reactants, catalyst, and electrolyte have the contact point of each other. To achieve maximum reaction rates, the effective surface area of active catalyst sites must be few times higher than the geometric surface area of the electrode. So, to construct a three-dimensional network, the electrodes are made porous in which the three-phase interfaces are situated. The catalyst surface area plays a major role in

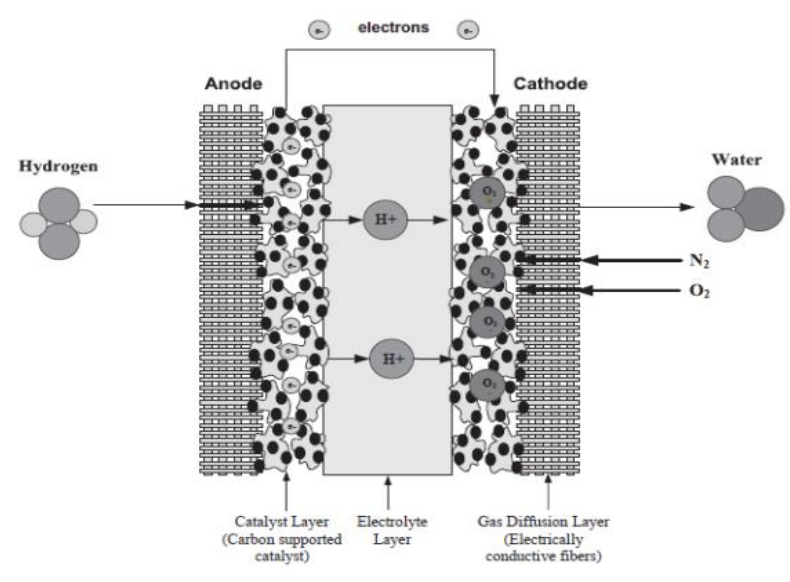

Fig. 1 - Schematic of the fuel cell catalyst layers

the catalyst layer; thus, it is highly desirable to have small particles ( $4 \mathrm{~nm}$ or smaller) with a large surface area homogenously distributed on the support material, which is mainly carbon powders with significant porosity and high surface area. Generally, the carbonbased support materials are Vulcan XC72, carbon nanotube, graphite powder, graphene etc. To determine the particle size distribution, on the basis of per-unit mass the particle surface area can be calculated by assuming all of the platinum particles are spherical:

$$
A_{s}=\frac{\int f(D) \pi D^{2} d D}{\int f(D) \rho_{P t}\left(\frac{\pi D^{3}}{6}\right) d D}=\frac{6}{\rho_{P t} D_{32}},
$$


where $\rho_{\mathrm{Pt}}$ is the density of the catalyst and $D_{32}$ is the mean diameter of all the particles. The active area per unit mass can be calculated from the mean $D_{32}$, and the value is around $28 \mathrm{~m}^{2} / \mathrm{g} \mathrm{Pt}$. The catalyst layer is supposed to be thin to minimize cell potential losses because of the rate of proton transport and reactant gas penetration in the depth of the electrocatalyst layer. So, the maximization of the metal active surface area is very important; therefore, higher $\mathrm{Pt} / \mathrm{C}$ ratios should be selected (> $40 \%$ by weight). However, from one of our previous work [3] it is observed that optimization of platinum loading at $40 \% \mathrm{Pt} / \mathrm{C}$ among three \% of electrocatalysts $(20 \%, 40 \%, 60 \% \mathrm{Pt} / \mathrm{C})$ exhibits significant increase in electrochemically active surface area and highest catalytic activity during ethanol electrooxidation. It has also been mentioned in the literature when the $\mathrm{Pt} / \mathrm{C}$ ratio was increased above $40 \%$, there is a decrease in cell performance. So, the performance of fuel cell can be increased by better Pt utilization in the catalyst layer, instead of increasing the Pt loading. The diffusion limitations inside the thin, porous backing layer or gas pores in the thin active layers are not necessary. So, the various classical models (simple pore [4], thin film [5], agglomerate [6] models) are used in PEMFC; the macro-homogeneous model for example has also been proposed for simulation of parameters related to PEMFC [7,8]. So, four main models have been recently used to explain the behaviour of the gas diffusion electrode. The applicability of a certain model will depend on electrode structure; Many of the models are microscopic models related with one element of the electrode producing the current (e.g., a thin film or a finite contact meniscus, etc.). The catalyst layer is having many phases: liquid, gas, different solids, and the membrane. Though various models have different equations, most of these are derived from the same equations, regardless of the effects being modelled. The anode reaction is being described by a Butler-Volmer-type expression in most of the cases except for those that use a fuel other than pure hydrogen. During the use of hydrocarbon like alcohol, glycerol and others, the platinum catalyst gets easily poisoned. Due to the adsorption of carbon monoxide at the electrocatalytic surface the reaction rate becomes very slow. There are different models in the literature that depicts a carbon monoxide site balance and examining the reaction steps involved. A few models are macroscopic and treated as continuum systems. But in the literature both microscopic and macroscopic models for the catalyst layer are there. In the microscopic model's spherical agglomerate models are called as special types, introduced by Antoine et al. [9]. The array of spherical agglomerates in these models are considered in three-dimensional hexagonal structures. There is the presence of gas pore or region flooded with electrolytes in the agglomerate models. The interactions between agglomerates are examined in these models. Ohm's law and Fick's law equations with kinetic expressions are solved in these models. The concentration around an electrocatalyst particle, and the placement of these particles helps to enhance or reduce the efficiency of the catalyst layer are obtained from the result of modelling. Experimental evidence (from our previous work [3]) supports a spherical agglomeratetype structure where the electrocatalyst $(40 \% \mathrm{Pt})$ is supported on a Vulcan XC 72 carbon base. We propose here a more realistic model allowing to show the specific effects of distribution of electrocatalyst as nanoparticles. At last, the model is used for determining the electrochemical parameters by comparing the experimental and ideal current-potential and electrochemical plots obtained with a Pt based active layer for ethanolic oxidation reaction. From this point of view, the model to be described in this article is a hybrid, with a microscopic partitioning of the electrode in metal-based catalyst and a macroscopic treatment of these catalysts.

This work represents a dynamic model for anode catalyst (40\% Pt/C) [3] of PEM fuel cell (Ethanol Fuel Cell), used for developing a simulation which could be compared with the ideal model catalysts. The model has been implemented in MATLAB that can be considered as a better platform for mathematical modelling.

\section{EXPERIMENTAL}

All simulations are carried out using MATLAB (2015 B, XP, WINDOWS7). Ideal model is being compared with the experimental model. The experimental model is Vulcan XC72 carbon supported $40 \% \mathrm{Pt}$ and its synthesis; morphological, electrochemical studies are already discussed [3]. Throughout the article, the Experimental Model and theoretical model are designated as EM and TM, respectively.

\section{RESULTS AND DISCUSSION}

Modelling of the anode catalyst layer of PEM fuel cell is being done using certain equations considering it as porous catalysts. Equations regarding the anode activation losses, liquid water rate of reaction, and hydrogen rate of reaction are given. At first step the Nernst voltage and voltage losses were calculated. The partial pressures of water, hydrogen, and oxygen are being used to calculate the Nernst voltage for this modelling:

First the calculation of the saturation pressure of water was done:

$\log P_{\mathrm{H} 2 \mathrm{O}}=-2.1794+0.02953 \cdot T_{c}-9.1837 \cdot 10^{-5} \cdot T_{c}^{2}+$ $1.4454 \cdot 10^{-7} \cdot T_{c}{ }^{3}$

$\log P_{\mathrm{H} 2 \mathrm{O}}=-2.1794+0.0295360-9.1837 \cdot 10^{-5} \cdot 60^{2}+$ $1.4454 \cdot 10^{-7} \cdot 0.467$

The partial pressure of hydrogen was calculated: $P_{\mathrm{H} 2}=0.5 \cdot\left(P_{\mathrm{H} 2} / \exp \left(1.653 \cdot i /\left(T_{k}{ }^{1.334}\right)\right)\right)-P_{\mathrm{H} 2 \mathrm{O}}=1.265$ $\left.P_{\mathrm{O} 2}=P_{\text {air }} / \exp \left(4.192 \cdot i /\left(T_{k}^{1.3334}\right)\right)\right)-P_{\mathrm{H} 2 \mathrm{O}}=2.527$

The voltage losses will now be calculated. The activation losses are estimated using the Butler-Volmer equation.

For the anode:

$$
i=i_{0}\left[\exp \left(\frac{\alpha_{A} n F}{R T} \eta\right)\right]-\exp \left(-\frac{\alpha_{C} n F}{R T} \eta\right),
$$

where $i$ is the electrode current density in $\mathrm{A} / \mathrm{m}^{2}, i_{0}$ is the exchange current density in $\mathrm{A} / \mathrm{m}^{2}, T$ is the absolute temperature in $\mathrm{K}, n$ is the number of electrons involved in the electrode reaction, $F$ is the Faraday constant, $R$ is the universal gas constant, $\alpha_{C}$ is the dimensionless cathodic charge transfer coefficient, $\alpha_{A}$ is the dimensionless anodic charge transfer coefficient, $\eta$ is the activation overpotential (defined as $E-E_{e q}$ ). 
The ohmic losses can be estimated using Ohm's law: $V_{\text {ohmic }}=-(i \cdot r)$.

The following equation shows the calculation of the Nernst voltage:

$$
E_{\text {Nernst }}=-\frac{G_{i, l i q}}{2 F}-\frac{R T_{k}}{2 F} \ln \left(\frac{P_{H 2 O}}{P_{H 2} P_{O 2}^{1 / 2}}\right) .
$$

As all voltage losses had a -ve sign in each equation so the actual voltage is the summation of the Nernst voltage plus the other voltage losses:

$$
V=E_{\text {Nernst }}+V_{\text {act }}+V_{\text {ohmic }}+V_{\text {conc }} .
$$

\section{SIMULATIONS}

For Experimental Model (EM), Theoretical Model (TM), the plots: (1) current density against the effectiveness factor, (2) current density against activation losses, (3) current density against the voltage (polarization curve), and (4) current density against the hydrogen flux density for ideal and experimental model are done by MATLAB. All the parameters required for these EM and TM system are listed in Table 1.

Table 1 - Parameters for modelling of EM and IM

\begin{tabular}{|l|l|l|}
\hline \multicolumn{1}{|c|}{ Parameter } & \multicolumn{1}{|c|}{ Value for TM } & \multicolumn{1}{c|}{ Value for EM } \\
\hline Temperature & $348.15 \mathrm{~K}$ & $348.15 \mathrm{~K}$ \\
\hline $\begin{array}{l}\mathrm{O}_{2} \text { permeation in } \\
\text { agglomerate }\end{array}$ & $1.5 \cdot 10^{-11}$ & $1.5 \cdot 10^{-11}$ \\
\hline $\begin{array}{l}\mathrm{H}_{2} \text { permeation in } \\
\text { agglomerate }\end{array}$ & $2 \cdot 10^{-11}$ & $2 \cdot 10^{-11}$ \\
\hline $\begin{array}{l}\text { Agglomerate ra- } \\
\text { dius in anode and } \\
\text { cathode }\end{array}$ & $110 \cdot 10^{-11}$ & $110 \cdot 10^{-11}$ \\
\hline Total gas pressure & $1 \mathrm{~atm}$ & $1 \mathrm{~atm}$ \\
\hline Hydrogen pressure & $1 \mathrm{~atm}$ & $1 \mathrm{~atm}$ \\
\hline Air pressure & $1 \mathrm{~atm}$ & $1 \mathrm{~atm}$ \\
\hline Saturation & $0.6 \cdot 10^{-12}$ & $0.6 \cdot 10^{-12}$ \\
\hline $\begin{array}{l}\text { Anode transfer } \\
\text { coefficient }\end{array}$ & 1 & 1 \\
\hline $\begin{array}{l}\text { Cathode transfer } \\
\text { coefficient }\end{array}$ & 0.9 & 0.9 \\
\hline $\begin{array}{l}\text { Constant ohmic } \\
\text { resistance }\end{array}$ & $0.02 \mathrm{Ohm}-\mathrm{cm}^{2}$ & $0.02 \mathrm{Ohm}-\mathrm{cm}^{2}$ \\
\hline $\begin{array}{l}\text { Limiting current } \\
\text { density }\end{array}$ & $1.4 \mathrm{~A} / \mathrm{cm}^{2}$ & $0.3 \mathrm{~A} / \mathrm{cm}^{2}$ \\
\hline $\begin{array}{l}\text { Mass transport } \\
\text { constant }\end{array}$ & 1.1 & 1.1 \\
\hline $\begin{array}{l}\text { Amplification } \\
\text { constant }\end{array}$ & 0.085 & 0.085 \\
\hline Gibbs function & $-228.170 \mathrm{~J} \cdot \mathrm{mol}^{-1}$ & $-228.170 \mathrm{~J} \cdot \mathrm{mol}^{-1}$ \\
\hline $\begin{array}{l}\text { Specific surface } \\
\text { area of catalyst }\end{array}$ & $1 \mathrm{~cm}{ }^{2}$ & $0.6 \mathrm{~cm}{ }^{2}$ \\
\hline Current density & $1 \mathrm{to} 1.2 \mathrm{~A} / \mathrm{cm}^{2}$ & $1 \mathrm{to} 1.2 \mathrm{~A} / \mathrm{cm}^{2}$ \\
\hline
\end{tabular}

Figures show the plotting of ideal and experimental model of anode catalyst (carbon supported $40 \% \mathrm{Pt}$ catalyst) with different variables. Current versus voltage, effectiveness factor and superficial flux density of hydrogen profiles over the active layer as well as polarization curves have been calculated and compared for the two models.

\section{Cell current versus voltage}

From Fig. 2 and Fig. 3, it is compared that the EM (agglomerate model) gives the lowest overvoltage if the same values are used for effective permeability and the same thickness of the active layer is assumed for both models.

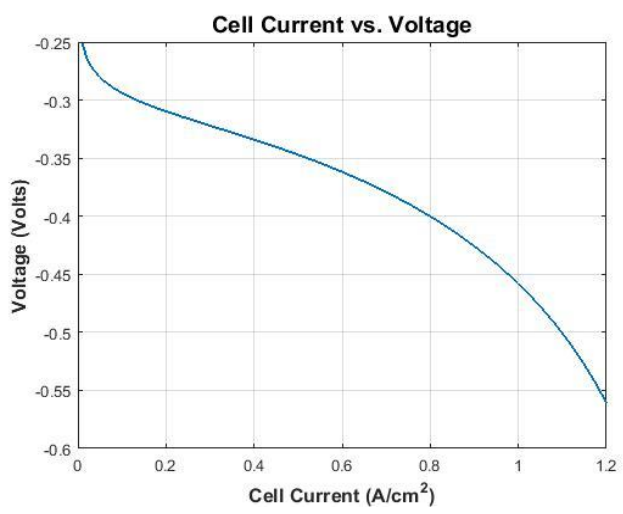

Fig. 2 - Cell current versus voltage of TM

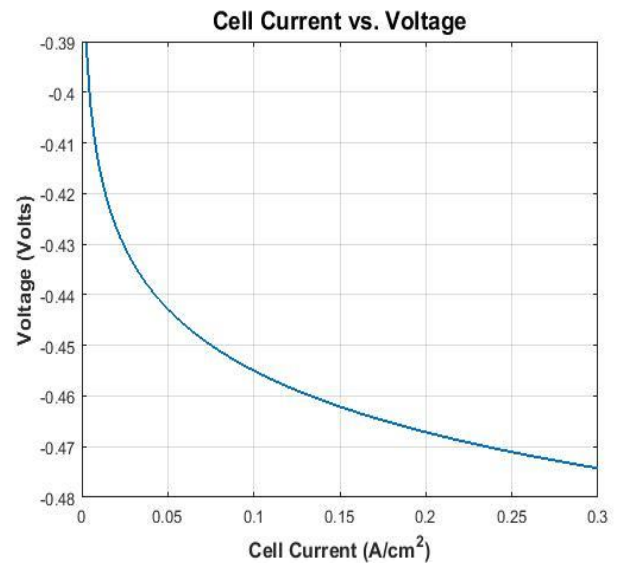

Fig. 3 - Cell current versus voltage of EM

\section{Effectiveness factors}

The definition of effectiveness factor of Pt utilization is the apparent rate of current conversion shown by specific catalyst layer divided by the ideal rate obtained provided all $\mathrm{Pt}$ atoms are used equally in electrochemical reactions at the specified electrode overpotential and externally supplied concentration of reactants. This definition incorporates statistical factors at all relevant scales along with non-uniformities of distributions of reaction rate under consideration. In the above Fig. 4 and Fig. 5, the effectiveness factors of two models are compared. Our experimental model (EM) is based on the spherical agglomerated morphology [3] of the catalyst layer. It depicts the interplay of transport phenomena and electrochemical kinetics. The limited effectiveness of $\mathrm{Pt}$ utilization in agglomerates is primarily an electrostatic effect in the mesoscopic scale. Fig. 4, shows that EM containing small radius of agglomerate, low operating current density result in increase in effectiveness factors of Pt. Finally, the comparative plots (Fig. 4 and Fig. 5) exhibit similar effectiveness factors of Pt utilization considering the surface to volume atom ratio of $\mathrm{Pt}$ nanoparticles. 


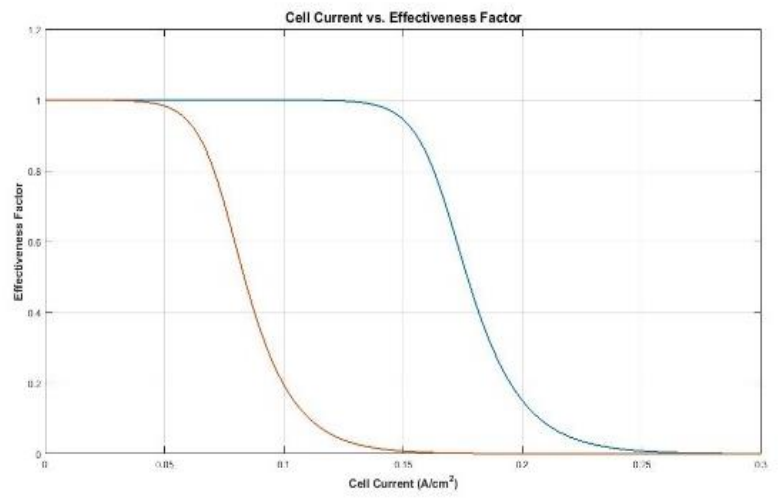

Fig. 4 - Cell current versus the effectiveness factor of EM

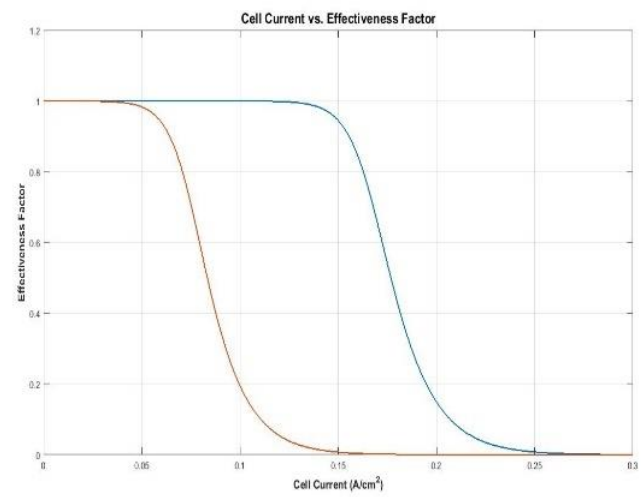

Fig. 5 - Cell current versus the effectiveness factor of TM

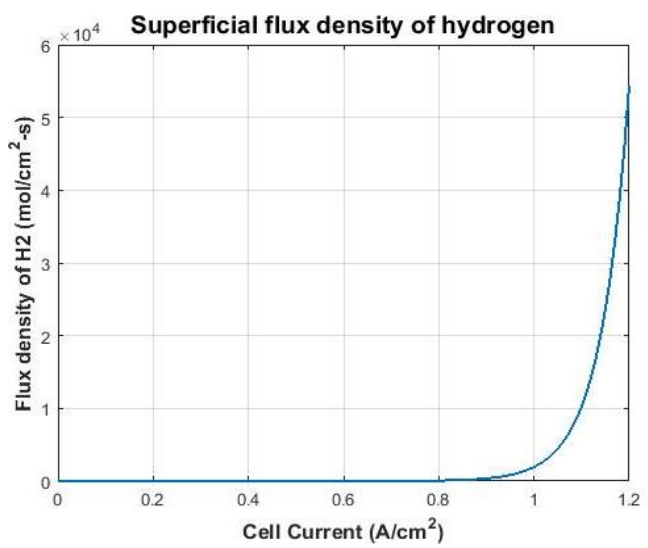

Fig. 6 - The flux density of hydrogen of TM

\section{Superficial flux density of hydrogen}

By comparing flux density of hydrogen (Fig. 6 and Fig. 7) EM is expected to be more effective than TM. For modeling of the catalyst, the main challenge is to find out the reliable parameters. The factors, like the rate determining step(s) of the electrochemical reaction, as well as the microstructure of the electrode on which the reference exchange current density, the effectiveness factors, and the reaction order depend. The model would be more difficult when the oxidation of various fluids (such as methane, carbon monoxide and hydrogen simultaneously or alcohols) are considered. Still there is no extensive study on reaction order and consequently the kinetic data of experiment are still less. Thus, it is required to establish exactly how simultaneous oxidations are occurred for different fuels by modeling.

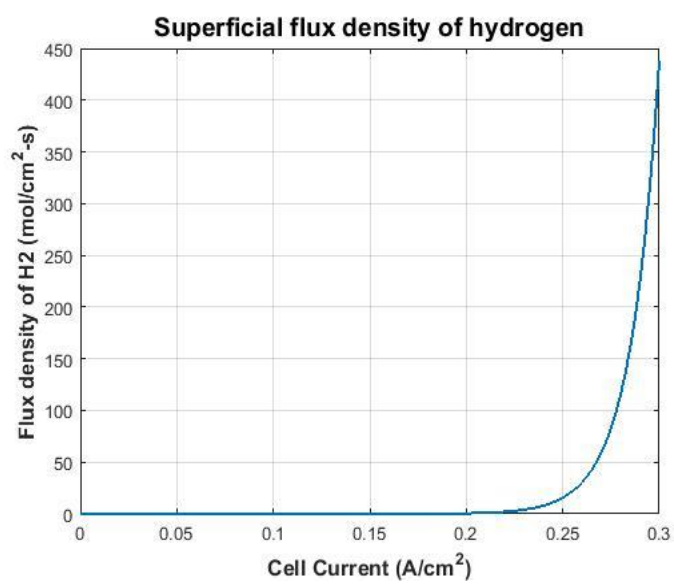

Fig. 7 - The flux density of hydrogen of EM

\section{CONCLUSIONS}

The optimization of catalyst composition and structure containing large electro-chemically active surface area are main factors to improve the performance of PEM fuel cells. Modelling studies are the valuable tools for investigating the effects of compositional optimization and structure of the catalyst layer. Some of the important phenomena which must be incorporated in the rigorous modelling of the catalyst layer including energy, mass, and charge balances as well as a relation that describes the contact between the porous gas diffusion layer (GDL) and polymer electrolyte membrane layer. Moreover, it is more challenging how the catalyst agglomerates are distributed on the GDL. For modelling the catalyst layer, the kinetics equations are very important and Tafel and the Butler-Volmer equations are commonly used equations. For the modelling of the catalyst layer many choices are available, and the complexity of the model must be determined by the required level of accuracy and the resources available to create the model. In addition, in the catalyst layers the detailed modelling of reactions can be used to determine methods for progressing the effectiveness of catalyst layers with a given platinum loading.

\section{ACKNOWLEDGEMENTS}

Authors are grateful to Amity University, Kolkata for the support, infrastructure provided to them.

\section{REFERENCES}

1. R.E. Yonoff, G.V. Ochoa, Y.C. Escorcia, J.I.S. Ortega, L.M. Stand, Heliyon 5, e01724 (2019).

2. R.L. Borup, A. Kusoglu, K.C. Neyerlin, R. Mukundan, R.K. Ahluwalia, D.A. Cullen, K.L. More, A.Z. Weber, D.J. Myers,

Cur. Opin. Electrochem. 21, 192 (2020).

3. S. Singh, J. Datta, Ionics 17, 785 (2011)

4. S. Srinivasan, H.D. Hurwitz, J.O'M. Bockris, J. Chem. Phys. 46, 3108 (1967). 
5. S. Srinivasan, H.D. Hurwitz, Electrochim. Acta 12, 495 (1967).

6. J. Giner, C. Hunter, J. Electrochem. Soc. 116, 1124 (1969).

7. D.M. Bernardi, M.W. Verbrugge, J. Electrochem. Soc. 139, 2477 (1992)
8. T.E. Springer, M.S. Wilson, S. Gottesfeld, J. Electrochem. Soc. 140, 3513 (1993).

9. O. Antoine, Y. Bultel, R. Durand, P. Ozil, Electrochim. Acta 43, 3681 (1998).

\title{
Моделювання шару каталізатора для полімерних електролітичних мембранних паливних елементів: підхід MATLAB
}

\author{
Susmita Singh ${ }^{1}$, Pushan Kumar Dutta ${ }^{2}$ \\ ${ }^{1}$ Department of Chemistry, Amity University, Kolkata, West Bengal, India \\ ${ }^{2}$ Department of Electronics and Communication Engineering, Amity University, Kolkata, West Bengal, India
}

Полімерний електролітичний мембранний паливний елемент (PEMFC) став новою технологією паливних елементів для стаціонарних і транспортних додатків. У роботі представлено моделювання шару каталізатора для системи PEMFC за допомогою MATLAB. Моделювання шару каталізатора $е$ багатопараметричною та багатокритеріальною проблемою. Моделювання шару каталізатора варіюеться від нуля до трьох вимірів. Фактична структура шару каталізатора не розглядаеться моделями нульового розміру. Загальні зміни в шарі каталізатора зображені одновимірними моделями. Дво- та тривимірні моделі враховують шар каталізатора та агломерат. У роботі представлена динамічна модель шару каталізатора для системи PEMFC з використанням MATLAB, який може бути використаний для розробки шару каталізатора. Запропонована модель включае різні умови експлуатації. Основна мета моделювання шару каталізатора полягае в тому, щоб вийти за рамки емпіричного опису характеристик паливного елемента, і моделювання проведено на основі певних параметрів із безпосередніми фізичними значеннями. Ця модель використовуеться для прогнозування підвищеної продуктивності шару каталізатора як функції таких вимірюваних характеристик, як власна активність каталізатора, ефективна площа поверхні, розмір агломерату, поліпшені електродні матеріали тощо. Кілька спрощуючих припущень роблять модель набагато простішою в обчислювальному плані і, отже, підходящою для моделювання не тільки шару каталізатора, але і всіеї системи елементів. Незважаючи на ці припущення, модель добре відтворюе експериментальні дані. Більше того, спостерігається, що запропонована динамічна модель каталізатора є дуже корисною у порівнянні з хімічно синтезованими каталізаторами.

Ключові слова: Полімерний електролітичний мембранний паливний елемент, Відновлювана енергія, Шар каталізатора, Динамічна модель. 